\title{
A QUALITATIVE SYSTEMATIC REVIEW EXPLORING SPIRITUALITY PERCEPTION AND EXPERIENCES OF CANCER PATIENTS
}

\author{
Ebru Akgun Citak ${ }^{1}$, Sultan Kav ${ }^{1}$, Banu Cevik¹. \\ ${ }^{1}$ Başkent University Faculty of Health Sciences, Nursing, Ankara, Turkey
}

\section{Introduction and Aim:}

Understanding the roles and contexts of spirituality among patients with cancer allows us to develop better supportive care.

The aim of the systematic review is to determine spirituality perception and experiences of cancer patients from qualitative studies.

\section{Methods}

Electronic databases (EBSCOhost, PubMed and WOS) were used for searching the studies with the following key words "spirituality", "cancer patient" and "qualitative study".

The methodology used for this systematic review was based on the Preferred Reporting Items for Systematic Reviews and Metaanalyses (PRISMA) guidelines.

Identified publications were screened by using the following inclusion criteria; qualitative studies and English language, full text journals, published in last 10 years. Reviews, conference abstracts, letters to the editor were excluded

\section{Results}

The initial search identified 89 articles and 13 studies met eligibility criteria. Majority of the studies were from USA (4) and Iran (4) rest of them were from UK, Taiwan, Thailand, Brazil, Canada, New Zealand and China. In most of the studies semi-structured interview were used while self-report questionnaires were used in two studies. Participants in these studies were breast cancer (3), advanced cancer (3), brain tumors (2), HSCT patients/survivors (2), colorectal cancer and mix group of cancer patients. In most studies, spirituality was identified as religious beliefs and relation with god. In one study, patient felt receiving specialized spiritual care would have a positive effect

\begin{tabular}{|c|c|c|c|}
\hline Study Title, Authors, Journal, Year & $\begin{array}{c}\text { Population/ } \\
\text { Country } \\
\end{array}$ & $\begin{array}{c}\text { Methods / } \\
\text { Analysis }\end{array}$ & Outcomes (Results) \\
\hline $\begin{array}{l}\text { 1.The use of spirituality and religiosity in coping with } \\
\text { colorectal cancer. Nejat N, Whitehead L, Crowe M. } \\
\text { Contemp Nurse. 2017; 53(1):48-59 }\end{array}$ & $\begin{array}{l}\text { Patients receiving adjuvant } \\
\text { treatment for colorectal } \\
\text { cancer; New Zealand } \\
(n=20) \& \text { Iran }(n=20)\end{array}$ & $\begin{array}{l}\text { Interview } \\
\text { Thematic } \\
\text { analysis }\end{array}$ & $\begin{array}{l}\text { The majority of participants interviewed used religion as a resource in coping with cancer. A minority } \\
\text { described spirituality as separate to religion and drew on spirituality either in relation to religion or alone. } \\
\text { All Iranian participants viewed spirituality as intertwined with religion. }\end{array}$ \\
\hline $\begin{array}{l}\text { 2. I'm Still Me: Inspiration and Instruction from Individuals with } \\
\text { Brain Cancer. Piderman Kmet al. } \\
\text { J Health Care Chaplain. 2017;23(1):15-33 }\end{array}$ & $\begin{array}{l}19 \text { patients with } \\
\text { brain cancer } \\
\text { USA }\end{array}$ & Interview & $\begin{array}{l}\text { Participants mentioned spirituality, meaning, and purpose in many contexts, including connecting with } \\
\text { family and friends, nature, art, music, and sometimes creating a relationship with God. Participants often } \\
\text { accessed spirituality by enhancing connections in their own lives: with a higher power, people, their work, } \\
\text { or themselves. }\end{array}$ \\
\hline $\begin{array}{l}\text { 3. Spiritual and religious assistance to cancer patients in the } \\
\text { hospital context. Freire MEM, Vasconcelos MFD, Silva TND \& } \\
\text { Oliveira KDL. Revista de Pesquisa: Cuidado é Fundamental } \\
\text { Online,2017;9(2),356-62 }\end{array}$ & $\begin{array}{l}25 \text { Mixed patient. } \\
\text { Brazil }\end{array}$ & $\begin{array}{l}\text { Interview } \\
\text { Content } \\
\text { analysis }\end{array}$ & $\begin{array}{l}\text { The results revealed that religiosity/spirituality is an important tactic in facing the oncologic disease, } \\
\text { considering that the patients interviewed reported the positive meaning of the support received, because } \\
\text { faith provides a constructive way of thinking. }\end{array}$ \\
\hline $\begin{array}{l}\text { 4. Stem Cell Transplantation Survivors: A Qualitative Approach. } \\
\text { Alaloul F, Schreiber JA, Al Nusairat TS, Andrykowski MA } \\
\text { Cancer Nurs. 2016;39(5):E39-47. }\end{array}$ & $\begin{array}{l}63 \mathrm{HSCT} \text { survivors } \\
\text { United states }\end{array}$ & $\begin{array}{l}\text { Self report } \\
\text { questionnaire } \\
\text { Thematic } \\
\text { analysis }\end{array}$ & $\begin{array}{l}\text { Three dimensions that helped patients cope with their experiences were identified: sickness viewed in light } \\
\text { of belief in God, use of religious/spiritual resources, and support from family and community. }\end{array}$ \\
\hline $\begin{array}{l}\text { 5. Religion as an Alleviating Factor in Iranian Cancer Patients: } \\
\text { a Qualitative Study. Rahnama M, Khoshknab M et.al. } \\
\text { Asian Pac J Cancer Prev. 2015;16(18):8519-24. }\end{array}$ & $\begin{array}{l}11 \text { Patients } \\
\text { Iran }\end{array}$ & $\begin{array}{l}\text { Content } \\
\text { analysis }\end{array}$ & $\begin{array}{l}\text { In general, relationship with God and religious beliefs had a positive effect on the patients adapting to } \\
\text { their condition, without negative consequences such as stopping their treatment process and just waiting } \\
\text { to be cured by God. }\end{array}$ \\
\hline $\begin{array}{l}\text { 6. Patient and healthcare perspectives on the importance and } \\
\text { efficacy of addressing spiritual issues within an interdisciplinary } \\
\text { bone marrow transplant clinic: a qualitative study. Sinclair S et al. } \\
\text { BMJ Open. } 2015 \text { 27;5(11):e009392. }\end{array}$ & $\begin{array}{l}7 \text { Bone morrow transplant } \\
\text { patients \& } 9 \text { family caregiver } \\
\text { Canada }\end{array}$ & $\begin{array}{l}\text { Interview } \\
\text { Content } \\
\text { analysis }\end{array}$ & $\begin{array}{l}\text { Both sets of participants felt that addressing basic spiritual issues was the responsibility of all members of } \\
\text { the interdisciplinary team, while recognising the need for specialised and embedded support from a } \\
\text { spiritual care professional. While healthcare providers felt that the impact of the illness and treatment had } \\
\text { a negative effect on patients' spiritual well-being, patients felt the opposite. }\end{array}$ \\
\hline $\begin{array}{l}\text { 7.Moving Beyond Suffering: the Experiences of Thai Persons With } \\
\text { Advanced Cancer. Nilmanat Ket al. } \\
\text { Cancer Nurs. 2015; 38(3):224-31. }\end{array}$ & $\begin{array}{l}15 \text { Mixed patients } \\
\text { Thailand }\end{array}$ & Interview & $\begin{array}{l}\text { Thai persons with advanced cancer tried to find ways to go on living with suffering. Three themes emerged } \\
\text { from the interview data: adopting religious doctrine, being hopeful, and being surrounded by the love and } \\
\text { care of the family }\end{array}$ \\
\hline $\begin{array}{l}\text { 8.Image of God, Religion, Spirituality, and Life Changes in Breast } \\
\text { Cancer Survivors: A Qualitative Approach. Schreiber JA, Edward J. } \\
\text { J Relig Health (2015) 54:612-622 }\end{array}$ & $\begin{array}{l}28 \text { women with breast } \\
\text { cancer } \\
\text { Iran }\end{array}$ & $\begin{array}{l}\text { Self report } \\
\text { questionnare }\end{array}$ & $\begin{array}{l}\text { Awareness of life and its fleeting nature was common to all. Behaviors ensuing from this awareness varied } \\
\text { from the need to focus on self-improvement, a sense of egocentrism (LE God), to the need to focus on } \\
\text { using what was learned through the cancer experience to help others, a sense of altruism (HE God). Study } \\
\text { results suggest that seemingly small, but highly meaningful, differences based on one's worldview result in } \\
\text { considerably different attitudinal and behavioral outcomes. }\end{array}$ \\
\hline $\begin{array}{l}\text { 9.Religion as an Empowerment Context in the Narrative of Women } \\
\text { with Breast Cancer. Sadati AK,et al } \\
J \text { Relig Health (2015) 54:1068-1079 }\end{array}$ & $\begin{array}{l}8 \text { women with breast cancer } \\
\text { Iran }\end{array}$ & Interview & $\begin{array}{l}\text { Two main themes discovered in this research were fatalism on the one hand, and the hope and } \\
\text { empowerment on the other. }\end{array}$ \\
\hline $\begin{array}{l}\text { 10.We both just trusted and leaned on the Lord": a qualitative study } \\
\text { of religiousness and spirituality among African American breast } \\
\text { cancer survivors and their caregivers. Sterba KR, et al. } \\
\text { Qual Life Res. 2014; 23(7):1909-20. }\end{array}$ & $\begin{array}{l}23 \text { women with breast } \\
\text { cancer \& } 22 \text { Primary } \\
\text { caregivers } \\
\text { USA } \\
\end{array}$ & Interview & $\begin{array}{l}\text { inner strength became coping and illness meaning and (2) transcendence became spiritual transcendence } \\
\text { and interpersonal transcendence. }\end{array}$ \\
\hline $\begin{array}{l}\text { 11. How women with advanced cancer pray: a report from two } \\
\text { focus groups. Smith AR et al. } \\
\text { Oncol Nurs Forum. 2012; 39(3):E310-6. }\end{array}$ & $\begin{array}{l}13 \text { Mixed adult patients } \\
\text { USA }\end{array}$ & Focus group & $\begin{array}{l}\text { Four themes emerged: finding one's own way, renewed appreciation for life, provision of strength and } \\
\text { courage, and gaining a stronger spiritual connection. In addition, praying for others, conversational prayer, } \\
\text { petitionary prayer, ritual prayer, and thanksgiving prayer were used most often by participants to cope. }\end{array}$ \\
\hline $\begin{array}{l}\text { 12. An exploration of spiritual needs of Taiwanese patients with } \\
\text { advanced cancer during the therapeutic processes. Hsiao SM et al. } \\
J \text { Clin Nurs. 2011;20(7-8):950-9 }\end{array}$ & $\begin{array}{l}33 \text { mixed patient } \\
\text { Taiwan and China }\end{array}$ & Interview & $\begin{array}{l}\text { Four spiritual needs emerged from the analysis: the need to foster hope for survival and obtain a peaceful } \\
\text { mindset, to fulfil the meanings of life and preserve one's dignity, to experience more reciprocal human love } \\
\text { and finally, to receive assistance in facing death peacefully }\end{array}$ \\
\hline $\begin{array}{l}\text { 13. The spiritual needs of neuro-oncology patients from patients' } \\
\text { perspective. Nixon A, Narayanasamy A. } \\
\text { J Clin Nurs. 2010; 19(15-16): 2259-2370. }\end{array}$ & $\begin{array}{l}43 \text { patients with brain cancer } \\
\text { UK }\end{array}$ & Interview & $\begin{array}{l}\text { These were reassurance, family support, need to talk, solitude, emotional support, need for } \\
\text { connection/loneliness/ depression, plans for the future/sense of normality, no spiritual needs, religious } \\
\text { needs and thoughts about meaning of life. }\end{array}$ \\
\hline
\end{tabular}

\section{Conclusions:}

Main focus of the studies was meaning of the spirituality, as a coping mechanism and spiritual care/support needs. 